\title{
A DNA biosensor for molecular diagnosis of Aeromonas hydrophila using zinc sulfide nanospheres
}

\author{
Masoud Negahdary ${ }^{1,2}$, Mahnaz Jafarzadeh ${ }^{3}$, Roya Rahimzadeh ${ }^{4}$, Ghasem Rahimi ${ }^{1}$, and \\ Hamideh Dehghani $^{2}$ \\ ${ }^{1}$ Young Researchers and Elite Club, Marvdasht Branch, Islamic Azad University, Marvdasht, Iran \\ ${ }^{2}$ Yazd Cardiovascular Research Center, Shahid Sadoughi University of Medical Sciences, Yazd, Iran \\ ${ }^{3}$ Young Researchers and Elite Club, Urmia Branch, Islamic Azad University, Urmia, Iran \\ ${ }^{4}$ Department of Biology, Payame Noor University, Tehran, Iran \\ Correspondence to: Masoud Negahdary (masoudnegahdary@ssu.ac.ir)
}

Received: 12 April 2017 - Revised: 18 June 2017 - Accepted: 20 June 2017 - Published: 27 July 2017

\begin{abstract}
Today, identification of pathogenic bacteria using modern and accurate methods is inevitable. Integration in electrochemical measurements with nanotechnology has led to the design of efficient and sensitive DNA biosensors against bacterial agents. Here, efforts were made to detect Aeromonas hydrophila using aptamers as probes and zinc sulfide $(\mathrm{ZnS})$ nanospheres as signal enhancers and electron transfer facilitators. After modification of the working electrode area (in a screen-printed electrode) with $\mathrm{ZnS}$ nanospheres through electrodeposition, the coated surface of a modified electrode with $\mathrm{ZnS}$ nanospheres was investigated through scanning electron microscopy (SEM). The size of synthesized $\mathrm{ZnS}$ nanospheres was estimated at about $20-50 \mathrm{~nm}$ and their shape was in the form of porous plates in microscopic observations. All electrochemical measurements were performed using cyclic voltammetry $(\mathrm{CV})$, electrochemical impedance spectroscopy (EIS), and constant potential amperometry (CPA) techniques. The designed DNA biosensor was able to detect deoxyribonucleic acid (DNA) of Aeromonas hydrophila in the range $1.0 \times 10^{-4}$ to $1.0 \times 10^{-9} \mathrm{~mol} \mathrm{~L}^{-1}$; the limit of detection (LOD) in this study was $1 \times 10^{-13} \mathrm{~mol} \mathrm{~L}^{-1}$. This DNA biosensor showed satisfactory thermal and $\mathrm{pH}$ stability. Reproducibility for this DNA biosensor was measured and the relative standard deviation (RSD) of the performance of this DNA biosensor was calculated as $5 \%$ during 42 days.
\end{abstract}

\section{Introduction}

Bacterial infections cause heavy losses on fish farms in the aquaculture industry (Austin and Austin, 2007; Gauthier, 2015; Shoemaker et al., 2001; Sommerset et al., 2014). Among the factors causing these losses, Aeromonas, particularly Aeromonas hydrophila, is highly regarded (Harikrishnan et al., 2015; Huang et al., 2015; Liu et al., 2013; Ponnusamy et al., 2016). This bacterium is facultative anaerobes, gram-negative, oxidase, and catalase positive (Cumberbatch et al., 1979; Popoff and Véron, 1976). Aeromonas hydrophila is ubiquitous and opportunistic in that it is one of the important bacteria in the warm-water fish culture industry, and sometimes it causes disease in saltwater fishes (Cipriano et al., 1984; Viswanatan et al., 2015). Aeromonas hydrophila is transmitted to fish through contaminated water or infected animals, and this bacterium may also cause some human diseases such as gastroenteritis and diarrhoea (Blake et al., 1980; Daskalov, 2006; Ljungh et al., 1977). Many different methods have been used for detection and determination of pathogenic bacteria, including solid and aqueous culture media (Kiyohara et al., 1982; Xie et al., 2005), gram stain (Nugent et al., 1991), biochemical studies (coagulase, oxidase, and catalase) (Hjelm et al., 2004; Raus and Love, 1983; Sumner and Taylor, 1989), impedance measurement (Suehiro et al., 2003), flow cytometry (Gunasekera et al., 2000), adenosine triphosphate (ATP) assessment (Chen and Godwin, 2006), polymerase chain reaction (PCR) (Belgrader et al., 1999), enzyme-linked immunosorbent assay (ELISA), and other novel techniques (Mansfield and 
Forsythe, 2000; Ruzicka et al., 2016). All conventional methods have at least one of these disadvantages: low detection accuracy, long time of detection, and the high detection cost (de Boer and Beumer, 1999; Gunasekera et al., 2000; Jorgensen and Turnidge, 2015; Megraud, 1996). Today, finding rapid and sensitive diagnostic techniques against pathogenic agents is very important. Since most of the time bacterial pollution is in low concentrations, and because of the worldwide prevalence of Aeromonas hydrophila, finding rapid and accurate diagnosis ways can prevent its prevalence; this matter is very important for world health (Ghali et al., 2016; Sebastian et al., 2016; Templier et al., 2016). Biosensors are analytical tools that can intelligently use biological materials to detect biochemical compound(s) and react to them $(\mathrm{Oz}-$ soz, 2012; Zhang et al., 2011); aptamers are used in conventional and optimized aptasensors based on their high affinity with a target and their specific function (Cosnier, 2015; Mascini, 2009; O'Sullivan, 2002; Radi et al., 2005). So far, several studies have been reported about the use of aptasensors to detect bacteria (Bagheryan et al., 2016; Hamidi-Asl et al., 2016; Kim et al., 2017; Li et al., 2016; Templier et al., 2016). Current research has shown new promising results about detection of bacterial pathogens at the gene level (Liébana et al., 2016; Lopez et al., 2016; Palchetti, 2016); accurate and rapid diagnostic methods against these pathogens are established through specific hybridization between aptamers and the single-stranded DNA (ssDNA) of bacteria (Jacobs and Bonham, 2016; Shachar et al., 2016; Sheikhzadeh et al., 2016). These biosensors that are capable of detecting the genes through hybridization of two strands of DNA are defined as a DNA biosensor (Beattie et al., 1995). A group of nanobiosensors can be produced by designing an interaction pathway between biological molecules and transducers; these nanobiosensors can be widely used for detection of biomolecules such as genes (Chiu and Huang, 2009; Pumera et al., 2007); producing these nanobiosensors via the construction of new nanomaterials and progressing their technological modifications is considered seriously in biosensing research (Chiu and Huang, 2009). Today, nanotechnology has affected various aspects of human life, and its applications domain is enhanced with the development of research in various fields (Brumfiel, 2003; Emerich and Thanos, 2003; Sahoo et al., 2007). Combining nanoparticles and biological components in a biosensor has been proposed as a powerful tool for pathogen detection (Deisingh and Thompson, 2004; Palchetti and Mascini, 2008; Zourob et al., 2008). Biosensors that use nanomaterials in their structure have a high efficiency and sensitivity due to the wide area of the immobilization surface in their bioreceptor. Thin layers of a $\mathrm{ZnS}$ semiconductor include one of the combinations from group II-VI semiconductors (Nanda et al., 2000). So far, $\mathrm{ZnS}$ nanoparticles have been used in several biomedical purposes (Malarkodi and Annadurai, 2013; Pawaskar et al., 2002; Wang and Hong, 2000). In this study a new molecular method has been introduced to detect Aeromonas hydrophila using electrochemical techniques in preparation of a sensitive and accurate DNA biosensor. Using molecular science and aptamers, detecting the DNA of Aeromonas hydrophila and accelerating the process of detection, using $\mathrm{ZnS}$ nanospheres, and designing the presented DNA biosensor were our important aims.

\section{Experiments}

\subsection{Reagents and materials}

Tris (hydroxymethyl) aminomethane (99\%), 6-Mercapto-1hexanol (MCH, $97 \%)$, dl-dithiothreitol (DTT) (1N), NaCl, $\mathrm{MgCl}_{2}, \mathrm{KCl}, \mathrm{NaOH}, \mathrm{KOH}, \mathrm{HCl}$, ethylacetate solution, ethanol solution, polyvinylpyrrolidone (PVP), polyvinyl alcohol (PVA), polyethylene glycol (PEG), zinc acetate dehydrate, sodium sulfide, sodium hydroxide, methylene blue (MB), blood agar (base), and deionized water (capacity $750 \mathrm{~mL}$ ) were purchased from Sigma-Aldrich (USA). Synthetic oligonucleotides for Aeromonas hydrophila were purchased from the Bioneer Corporation (South Korea) as below:

- probe ssDNA (pssDNA): sequence 5' - thiolated -GAT CCG GGC CTC ATG TCG TTCGAA-3';

\section{- target ssDNA (ssDNA): sequence 5'-AAC CTG GTT CCG CTC AAG CCG TTG-3'.}

All other used materials were provided through certified companies.

\subsection{Apparatus and experiment procedures}

Several screen-printed carbon electrodes (ref. DRP-C110) were used during all experiments with the information below:

- working electrode: carbon (4 mm diameter);

- auxiliary electrode: carbon;

- reference electrode: silver;

and a cable connector as an interface between electrodes and a potentiostat device that was provided by DropSens (Spain). All electrochemical studies were performed through a computer-controlled $\mu$-Autolab electrochemical potentiostat device that was equipped with General Purpose Electrochemical System (GPES) and Frequency Response Analyzer (FRA2) software (version 4.7) (Eco Chemie Ultecht, the Netherlands). All electrochemical experiments were done in a $10 \mathrm{ml}$ voltammetric cell containing a Tris- $\mathrm{HCl}$ buffer as the binding solution $(50 \mathrm{mM}$ Tris- $\mathrm{HCl}, 100 \mathrm{mM} \mathrm{NaCl}$, $15 \mathrm{mM} \mathrm{KCl}, 10 \mathrm{mM} \mathrm{MgCl} 2$, and 5\% ethanol; $\mathrm{pH} 7.4)$. In this research, some electrochemical measurement techniques such as electrochemical impedance spectroscopy (EIS) and 

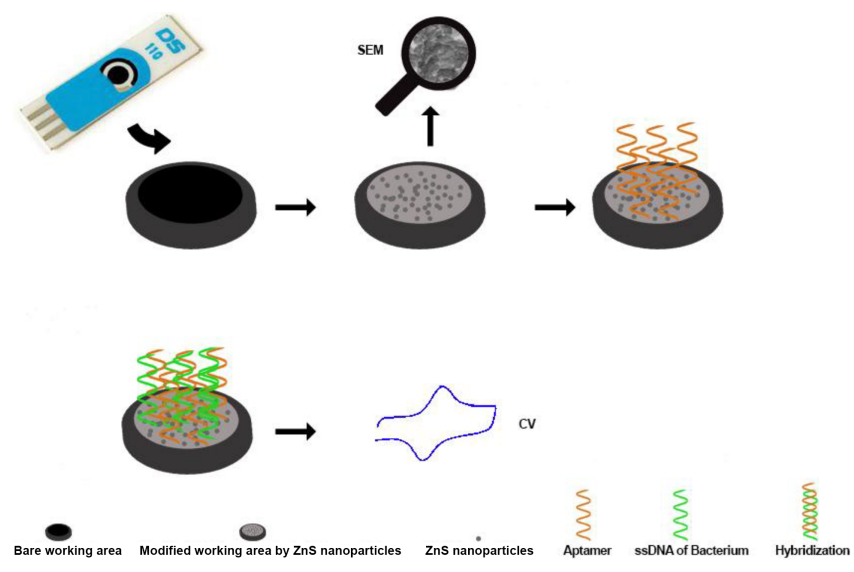

Figure 1. Schematic procedure to design and detect Aeromonas hydrophila; all actions were performed on a working area in a screenprinted electrode; the steps to design it were preparation of a bare electrode, modification with $\mathrm{ZnS}$ nanospheres, aptamer immobilization, hybridization for aptamers and Aeromonas hydrophila DNA and a product electrochemical redox signal respectively.

cyclic voltammetry $(\mathrm{CV})$ were applied to detect related analytes. The size and morphology of coated $\mathrm{ZnS}$ nanospheres through electrodeposition $(-0.6 \mathrm{~V}$ for $200 \mathrm{~s})$ on the surface of the working area in a screen-printed electrode were investigated by SU3500 Premium VP-SEM scanning electron microscopes (Japan). All other used devices included a pH meter, refrigerator, digital scale, and DNA hybridization incubator that were prepared by valid companies. ZnS nanospheres were synthesized according to a previously used reported protocol by us (Dehghani et al., 2016); the summarized details for the used protocol are as below.

In this procedure, $\mathrm{ZnS}$ nanospheres were synthesized through a co-precipitation technique using PVP, PVA, and PEG (Bandaranayake et al., 1995; Cheng et al., 2004; Griffith, 1961). In this technique, precipitation occurred in involved metal ions with sulfide ions within production solution. Firstly, zinc acetate dihydrate $(0.1 \mathrm{M})$ and sodium sulfide $(0.1 \mathrm{M})$ were mixed together through capping agent solutions including PVP, PVA, and PEG. Then, other production steps were done and the achieved solution was inserted at $80^{\circ} \mathrm{C}$ for $4 \mathrm{~h}$ to obtain $\mathrm{ZnS}$ nanospheres in a powder state; the achieved solution in previous steps was used for electrodeposition via a potentiostat device $(-0.6 \mathrm{~V}$ for 200 s). The colour change in the working surface area in the screen-printed electrode was seen after successful electrodeposition, and this change was from black to grey; this schematic process is shown in Fig. 1. A sequence 5'- thiolated oligonucleotide probe (sequence 5'- thiolated -GAT CCG GGC CTC ATG TCG TTCGAA-3') was used to increment the covalent attachment affinity in the hybridization and detection process against Aeromonas hydrophila target single-stranded DNA (ssDNA) (5'-AAC CTG GTT CCG CTC AAG CCG TTG-3'). The disulfide protecting group in
Table 1. Various statuses of used electrodes in electrochemical experiments.

\begin{tabular}{lccc}
\hline $\begin{array}{l}\text { Electrode } \\
\text { type status }\end{array}$ & $\begin{array}{c}\text { Existence } \\
\text { of ZnS nanospheres }\end{array}$ & $\begin{array}{c}\text { Existence } \\
\text { of pssDNA }\end{array}$ & $\begin{array}{c}\text { Existence } \\
\text { of tssDNA }\end{array}$ \\
\hline Type 1 & + & + & - \\
Type 2 & + & + & + \\
Type 3 & - & + & + \\
Type 4 & + & - & + \\
Type 5 & - & - & + \\
\hline + existence; - non-existence.
\end{tabular}

pssDNA was removed and broken using $10 \mu \mathrm{L}$ of dithiothreitol (DTT) $100 \mathrm{mM}$ buffer solution at $\mathrm{pH} 5.0$ dropped in the aptamer's stock for $30 \mathrm{~min}$ at $25^{\circ} \mathrm{C}$ and then, in order to remove excess DTT, the extraction aptamer's vial four times (each time with $300 \mu \mathrm{L}$ of ethyl acetate solution). Due to the preparation protocols, first $380 \mu \mathrm{L}$ of deionized water were added to each lyophilized primer stock; the achieved con-

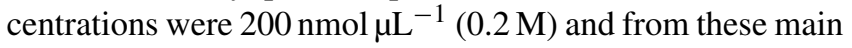
stocks all needed concentrations were prepared and diluted (aptamer preparation solution properties: Tris- $\mathrm{HCl}$ buffer (30 mM Tris- $\mathrm{HCl}, 200 \mathrm{mM} \mathrm{NaCl} ; \mathrm{pH}$ 8.4). The main aptamer stock vials were kept frozen $\left(-20^{\circ} \mathrm{C}\right)$ when not used. Singlestranded and paired aptamers were heated at $95^{\circ} \mathrm{C}$ and then cooled at room temperature $\left(25^{\circ} \mathrm{C}\right)$ for $20 \mathrm{~min}$ to find them in dehybridization status (in paired status) and the best conformational structure (in single-stranded status); this condition was frequently repeated during some experiments. In one of the first procedure steps, the surface of the screenprinted electrode was rinsed with deionized water and dried with nitrogen. Then $5 \mu \mathrm{L}$ of $20 \mathrm{mM}$ of pssDNA were filled on the surface of the working area as a dropping. To have the best aptamer sequence immobilization time on the surface of a modified working area with $\mathrm{ZnS}$ nanospheres in a screen-printed electrode, the open circuit potential (OCP) technique was applied and the best aptamer sequence immobilization time calculated as $3 \mathrm{~h}$. The screen-printed electrode was stored at $4{ }^{\circ} \mathrm{C}$ during the immobilization process; after this time period, the electrode was washed regularly with deionized water and 6-Mercapto-1-hexanol to remove all unbounded aptamers from the surface of it. The hybridization process between pssDNA and tssDNA was performed in a DNA hybridization incubator $\left(37^{\circ} \mathrm{C}, 45 \mathrm{~min}\right)$ for each prepared concentration separately. The schematic procedure for designing and detecting Aeromonas hydrophila is shown in Fig. 1.

Before each electrochemical measurement $10 \mu \mathrm{L}$ of MB $(50 \mathrm{mM})$ were used and dropped onto the surface of the working area as a redox marker in all electrochemical experiments (the time for binding between MB and aptamer was $10 \mathrm{~min}$ ); $\mathrm{MB}$ has a high strong interaction with guanine bases in single-strand DNA. Every time that the pssDNA aptamer was hybridized with another tssDNA aptamer, the possibil- 


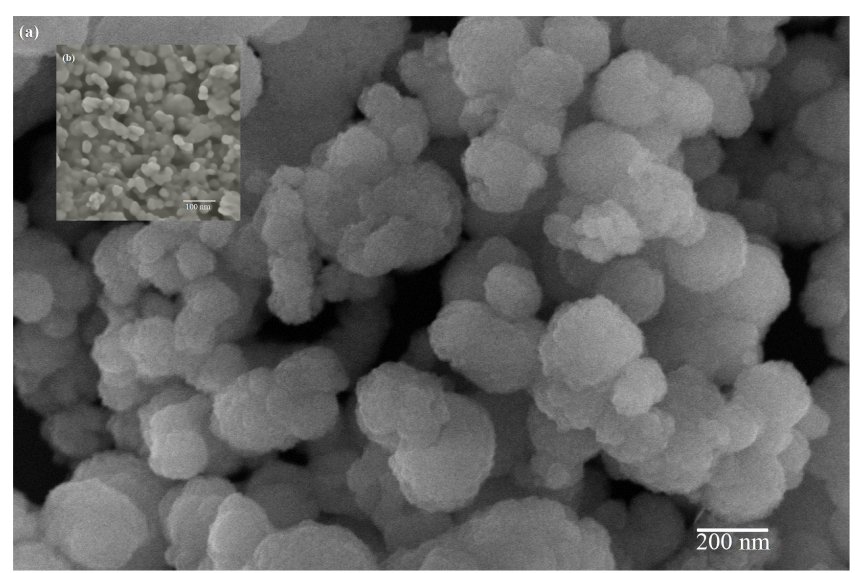

Figure 2. SEM images of synthesized ZnS Nps with different magnifications: (a) magnification was $40000 \times$ and the scale bar was $200 \mathrm{~nm}$; (b) magnification was $4000 \times$ and the scale bar was $100 \mathrm{~nm}$.

ity of tagging and influencing MB molecules with the aptamer was decreased. This feature caused the creation of a shift in different peaks in various concentrations of the analyte. The maximum access state of MB and pssDNA aptamer molecules to each other was found in the absence of the tssDNA; the minimum access state of MB and pssDNA aptamer molecules to each other was found in the presence of the highest concentration of tssDNA; EIS and CV were performed in a $10 \mathrm{~mL}$ electrolyte cell $(50 \mathrm{mM}$ Tris- $\mathrm{HCl}, 100 \mathrm{mM}$ $\mathrm{NaCl}, 15 \mathrm{mM} \mathrm{KCl}, 10 \mathrm{mM} \mathrm{MgCl}$, and $5 \%$ ethanol; $\mathrm{pH}$ 7.4). Electrochemical experiments were performed in various statuses that are shown in Table 1; this test was performed to find the selectivity of the designed DNA biosensor.

Evaluation of real samples was performed using 10 salmon that suffered from Aeromonas hydrophila. Initially, biopsies of their kidneys and livers were performed; then, Aeromonas hydrophila was cultured and incubated for $24 \mathrm{~h}$ on blood agar at $22^{\circ} \mathrm{C}$ for use in PCR. Aeromonas hydrophila DNA amplification was performed through the PCR technique via the Mastercycler nexus (Eppendorf, Germany). In the next step, Aeromonas hydrophila DNA extraction was performed using a PCR kit (MBS598131 - mybiosource-USA); to obtain the concentration of the extracted DNA, a UV-Vis spectrophotometer was used (Thermo Scientific NanoDrop, USA). Then, real samples (tssDNA) were hybridized with pssDNA and redox peaks were achieved to compare and validate the optimal performance of the designed electrochemical DNA biosensor. To find an optimized DNA biosensor, some other tests were also performed, such as regeneration, reproducibility, stability, interference effects, $\mathrm{pH}$ effect, and temperature effect.

\section{Results and discussion}

\subsection{Scanning electron microscopy (SEM) investigation}

Sample topography features, including surface properties, surface morphology of the sample (including shape, size, and located position of particles on the surface of materials), composition, and characteristics of the components, make it determined via SEM (Goldstein, 1992). In most recent studies on the properties of nanostructures, SEM was used to investigate the items including particle size, shape, structure, and surface crystallography (Goldstein et al., 2012). In this research, after modification of electrodes with $\mathrm{ZnS}$ nanospheres, the coated surface of electrodes was studied through SEM, and it is found that the particles size was about 20-50 $\mathrm{nm}$. SEM images revealed that the shape of these particles was similar to porous plates with high roughness, and it was used as a nice feature for successful attachment of aptamers to the surfaces of electrodes. The specific morphology of $\mathrm{ZnS}$ nanospheres provided an increased surface for attachment of aptamers; in addition, high reactivity and expanded electron transfer capability were found on this surface based on special shapes of $\mathrm{ZnS}$ nanospheres. Figure 2 shows related images of $\mathrm{ZnS}$ nanospheres with different magnifications. In Fig. 2a, magnification was $40000 \times$ and the scale bar was $200 \mathrm{~nm}$, and in Fig. 2b, magnification was $4000 \times$ and the scale bar was $100 \mathrm{~nm}$. At higher magnification it is shown that there is an appropriate surface for strong attachment of biological components such as aptamers.

\subsection{Finding the best hybridization time for the Aeromonas hydrophila DNA biosensor}

The prepared DNA biosensor was incubated 10 times consecutively (every $5 \mathrm{~min}$ ) and during hybridization a constant concentration of tssDNA is used $\left(1.0 \times 10^{-6} \mathrm{~mol} \mathrm{~L}^{-1}\right)$. The results of this test showed that the best hybridization time for the Aeromonas hydrophila DNA biosensor occurred $45 \mathrm{~min}$ after first incubation and that the peak current was $-110 \mu \mathrm{A}$ at this time; the related calibration equation was $y=-2.0848 x-8.6667, R^{2}=0.9917$ (Fig. 3). This optimized time was used in all other hybridization experiments.

\subsection{Main electrochemical measurements}

The EIS technique is one of the useful electrochemical measurements that help to find the best probing features of surface-modified electrodes (Chang and Park, 2010; Orazem and Tribollet, 2011; Retter and Lohse, 2005). This technique also provides the investigation of the formation and quality of working electrode behaviour. In this research EIS was applied with a frequency of $0.05-100 \mathrm{kHz}$ in various electrode types $(n=1-4)$. A constant concentration of tssDNA was used $\left(1.0 \times 10^{-6} \mathrm{~mol} \mathrm{~L}^{-1}\right)$ in all electrodes to perform this test. The test was performed in a $10 \mathrm{~mL}$ electrolyte cell $(50 \mathrm{mM}$ Tris- $\mathrm{HCl}, 100 \mathrm{mM} \mathrm{NaCl}, 15 \mathrm{mM} \mathrm{KCl}, 10 \mathrm{mM}$ 


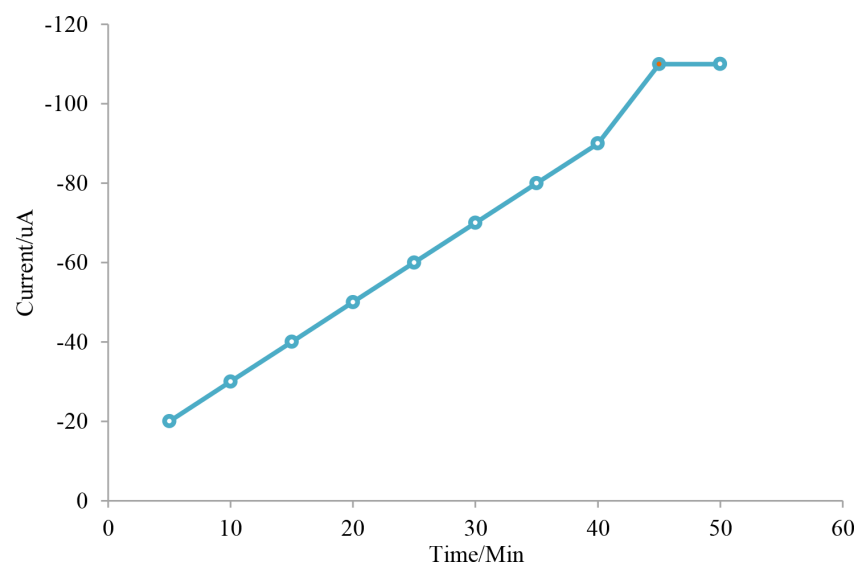

Figure 3. Best hybridization time for the Aeromonas hydrophila DNA biosensor in time range 5-50 min; the optimum was $45 \mathrm{~min}$.

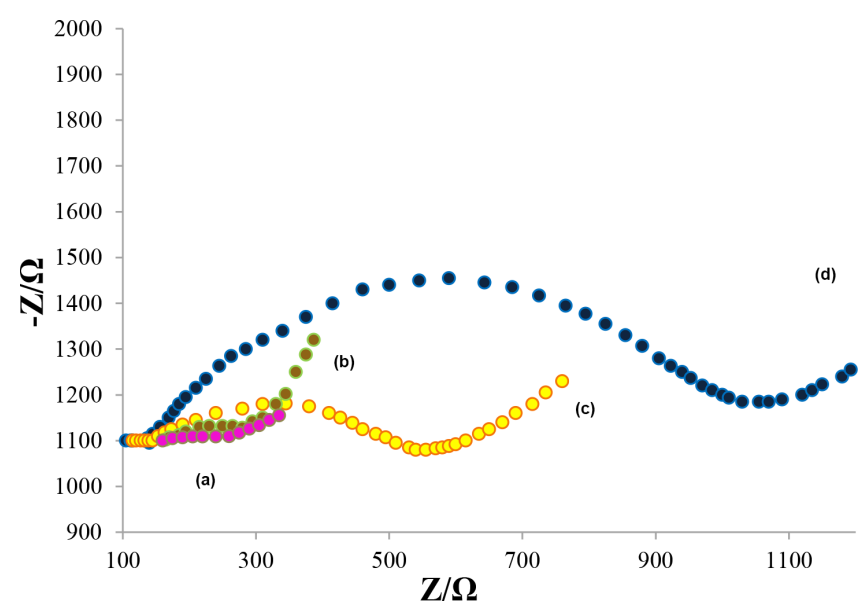

Figure 4. EIS; (a) electrode with tssDNA; (b) electrode with $\mathrm{ZnS}$ nanospheres and tssDNA; (c) electrode with pssDNA and tssDNA; (d) electrode with $\mathrm{ZnS}$ nanospheres, pssDNA, and tssDNA; electrolyte binding buffer $(50 \mathrm{mM}$ Tris- $\mathrm{HCl}, 100 \mathrm{mM} \mathrm{NaCl}, 15 \mathrm{mM}$ $\mathrm{KCl}, 10 \mathrm{mM} \mathrm{MgCl}_{2}$, and $5 \%$ ethanol; $\mathrm{pH} 7.4$ ); the frequency for EIS was $0.05-100 \mathrm{kHz}$.

$\mathrm{MgCl}_{2}$, and $5 \%$ ethanol; $\left.\mathrm{pH} 7.4\right)$. Output results were provided just for electrode type 2 (curve d), electrode type 3 (curve c), electrode type 4 (curve b), and electrode type 5 (curve a), and the Nyquist plots are shown in Fig. 4. The EIS test was not investigated for electrode type 1, because this electrode did not contain any tssDNA of Aeromonas hydrophila. The impedance response for electrode type 2 (curve c) was larger and showed more successful electron charge transfer than other electrodes. There was a little heterogeneous resistance to charge transfer (Rct) in the bare electrode (curve b), and this phenomenon strongly increased in electrode type 2 (curve c).

In another experiment the $\mathrm{CV}$ technique was applied for various concentrations of Aeromonas hydrophila tssDNA (Fig. 5). The used concentrations were $1.0 \times 10^{-4} \mathrm{~mol} \mathrm{~L}^{-1}$

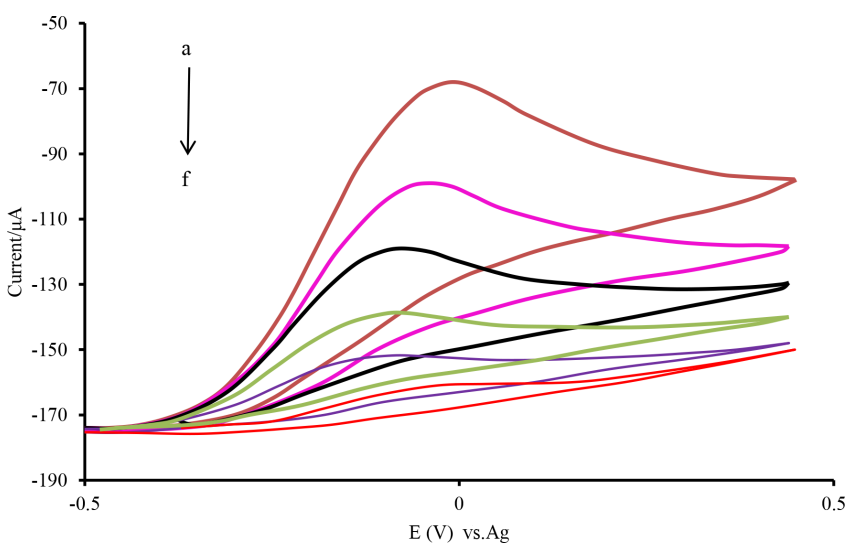

Figure 5. Cyclic voltammograms of hybridized pssDNA with various concentrations of Aeromonas hydrophila tssDNA $\left(1.0 \times 10^{-4} \mathrm{~mol} \mathrm{~L}^{-1}\right.$ (curve a), $1.0 \times 10^{-5} \mathrm{~mol} \mathrm{~L}^{-1}$ (curve b), $1.0 \times 10^{-6} \mathrm{~mol} \mathrm{~L}^{-1}$ (curve c), $1.0 \times 10^{-7} \mathrm{~mol} \mathrm{~L}^{-1}$ (curve d), $1.0 \times 10^{-8} \mathrm{~mol} \mathrm{~L}^{-1}$ (curve e), and $1.0 \times 10^{-9} \mathrm{~mol} \mathrm{~L}^{-1}$ (curve f)).

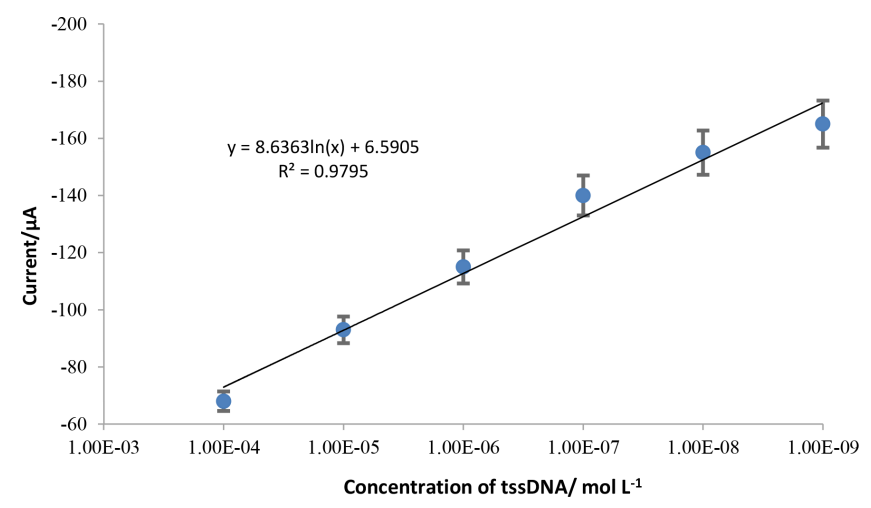

Figure 6. Calibration diagram of hybridized pssDNA with various concentrations of Aeromonas hydrophila tssDNA $\left(1.0 \times 10^{-4}, 1.0 \times 10^{-5}, 1.0 \times 10^{-6}, 1.0 \times 10^{-7}, 1.0 \times 10^{-8}\right.$, and $\left.1.0 \times 10^{-9} \mathrm{~mol} \mathrm{~L}^{-1}\right)$.

(curve a), $1.0 \times 10^{-5} \mathrm{~mol} \mathrm{~L}^{-1}$ (curve b), $1.0 \times 10^{-6} \mathrm{~mol} \mathrm{~L}^{-1}$ (curve c), $1.0 \times 10^{-7} \mathrm{~mol} \mathrm{~L}^{-1}$ (curve d), $1.0 \times 10^{-8} \mathrm{~mol} \mathrm{~L}^{-1}$ (curve e), and $1.0 \times 10^{-9} \mathrm{~mol} \mathrm{~L}^{-1}$ (curve f). This test was performed in a $10 \mathrm{~mL}$ electrolyte cell $(50 \mathrm{mM}$ Tris- $\mathrm{HCl}$, $100 \mathrm{mM} \mathrm{NaCl}, 15 \mathrm{mM} \mathrm{KCl}, 10 \mathrm{mM} \mathrm{MgCl}_{2}$, and $5 \%$ ethanol; $\mathrm{pH}$ 7.4). The peak current was decreased while concentrations were increased continuously; the $1.0 \times 10^{-9} \mathrm{~mol} \mathrm{~L}^{-1}$ concentration was considered the maximum response for the Aeromonas hydrophila DNA biosensor; peak current was constant for more concentrations than $1.0 \times 10^{-9} \mathrm{~mol} \mathrm{~L}^{-1}$.

The calibration diagram for mentioned concentrations of Aeromonas hydrophila tssDNA and their hybridization process with pssDNA are shown in Fig. 6. The relation between peak currents and various concentrations was calculated as a logarithmic equation $(y=8.64 \ln (x)+6.6)$; in addition, $R$ squared was investigated $\left(R^{2}=0.98\right)$. These results 


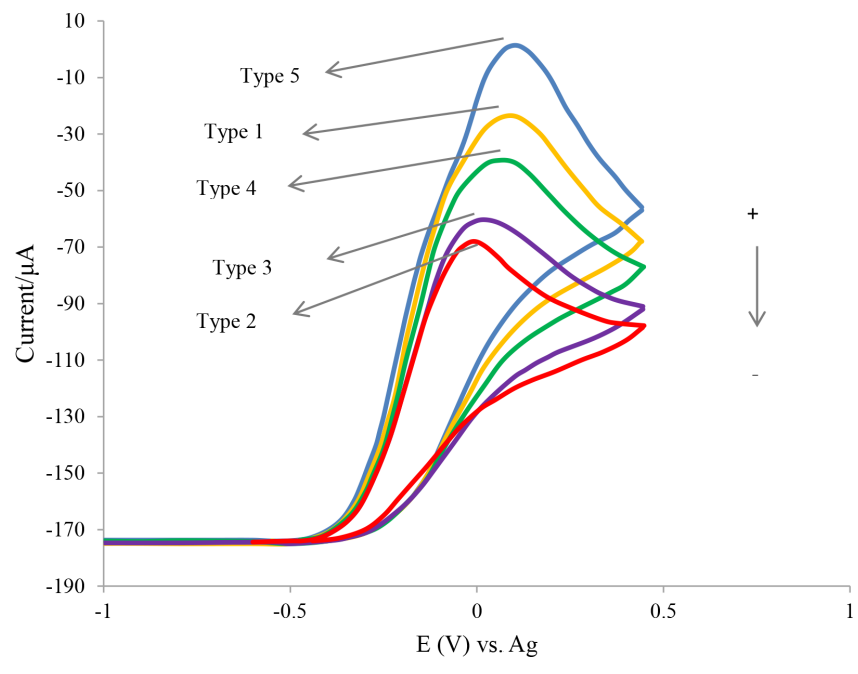

Figure 7. Selectivity test of the response of the Aeromonas hydrophila DNA biosensor through various electrodes. Electrode type 2: existence of $\mathrm{ZnS}$ nanospheres, pssDNA, and tssDNA; electrode type 3: existence of pssDNA and tssDNA; electrode type 4: existence of $\mathrm{ZnS}$ nanospheres and tssDNA; electrode type 1: existence of $\mathrm{ZnS}$ nanospheres and pssDNA; electrode type 5: existence of tssDNA.

confirmed that there was a linear relation between analyte concentrations and peak current reductions.

\subsection{Selectivity test of the response of the Aeromonas hydrophila DNA biosensor}

A selectivity test of the response of the Aeromonas hydrophila DNA biosensor was performed using five electrodes with different statuses. A constant concentration of tssDNA was used $\left(1.0 \times 10^{-6} \mathrm{~mol} \mathrm{~L}^{-1}\right)$ to perform this test in all electrodes. This test was performed in a $10 \mathrm{~mL}$ electrolyte cell $(50 \mathrm{mM}$ Tris- $\mathrm{HCl}, 100 \mathrm{mM} \mathrm{NaCl}, 15 \mathrm{mM} \mathrm{KCl}, 10 \mathrm{mM}$ $\mathrm{MgCl}_{2}$, and $5 \%$ ethanol; $\mathrm{pH}$ 7.4). The maximum response was found in electrode type 2 that applied the existence of $\mathrm{ZnS}$ nanospheres, pssDNA, and tssDNA to it (Fig. 7). The coated surface of the working area in a screen-printed electrode with $\mathrm{ZnS}$ nanospheres provided a proper state for immobilization of aptamers on the surface of it; this nanoelectrode also contributed a successful redox reaction against other electrode statuses. Electrode type 2 was selected for all bioelectrochemical experiments. The results of this test showed that this DNA biosensor is applicable for electrode types 2 and 3 . The other electrode types are not applicable for detecting Aeromonas hydrophila, because any hybridization between pssDNA and tssDNA did not occur in them. The difference between peaks in other electrodes was related to different tendencies of the MB redox agent versus each electrode, which led to the production of different electrochemical signals.

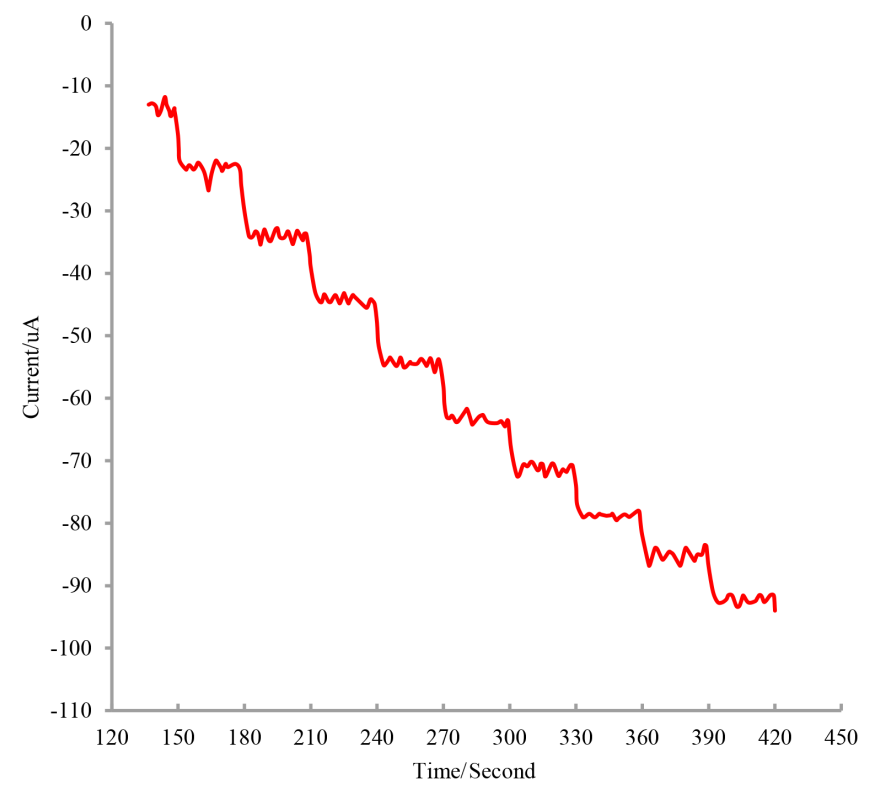

Figure 8. Constant potential amperometry responses of the Aeromonas hydrophila DNA biosensor during 137-415 s; rotating speed was $500 \mathrm{rpm}$. This test was performed in a $10 \mathrm{~mL}$ electrolyte cell (50 mM Tris- $\mathrm{HCl}, 100 \mathrm{mM} \mathrm{NaCl}, 15 \mathrm{mM} \mathrm{KCl}, 10 \mathrm{mM} \mathrm{MgCl}_{2}$, and $5 \%$ ethanol; $\mathrm{pH} 7.4)$.

In the next experiment, the Aeromonas hydrophila DNA biosensor was investigated and its behaviour was followed by the CPA technique. This technique was applied to investigate the efficiency of the designed Aeromonas hydrophila DNA biosensor, and it is very useful to find real interactions among substrate concentration and biosensor results (Arrigan, 2015; Jiang, 2007; Wang, 2006). So far, the CPA technique has been considered a highly sensitive electrochemical technique. Here, CPA responses for the Aeromonas hydrophila DNA biosensor were followed during 137-415 s and the rotating speed was $500 \mathrm{rpm}$; this test was continued till a non-Faradaic current found a stable level. In Fig. 8, the step-wise array of time/second was versus current $(\mu \mathrm{A})$. In this experiment several concentrations of tssDNA were used, the output results showed a good stable state, and DNA biosensor feedback was acceptable. This test was performed in a $10 \mathrm{~mL}$ electrolyte cell $(50 \mathrm{mM}$ Tris- $\mathrm{HCl}, 100 \mathrm{mM} \mathrm{NaCl}$, $15 \mathrm{mM} \mathrm{KCl}, 10 \mathrm{mM} \mathrm{MgCl}_{2}$, and $5 \%$ ethanol; $\mathrm{pH}$ 7.4).

\section{5 $\mathrm{pH}$ effect on the response of the Aeromonas hydrophila DNA biosensor}

Bacteria indicate variable growth and activity at various $\mathrm{pH}$ values. Here the $\mathrm{pH}$ effect on the response of the Aeromonas hydrophila DNA biosensor was investigated in $\mathrm{pH}$ range 210 (Fig. 9). The optimum activity response of this designed DNA biosensor was found at $\mathrm{pH} 7$ when the peak current was $-140 \mu \mathrm{A}$. After the optimum point ( $\mathrm{pH} 7)$, a severe decline was observed in the activity of this designed DNA biosensor, 


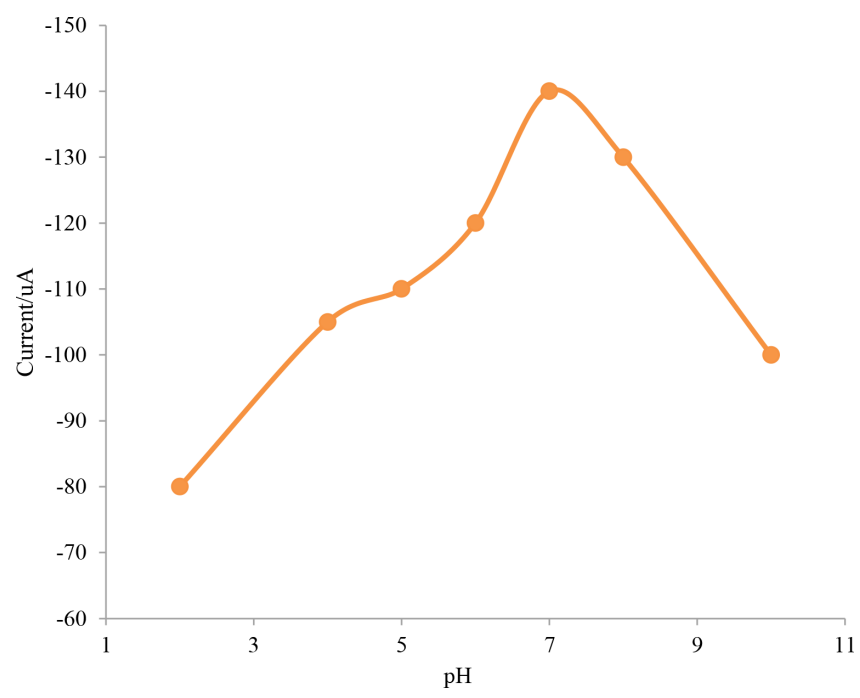

Figure 9. $\mathrm{pH}$ effect on Aeromonas hydrophila DNA biosensor response in $\mathrm{pH}$ range 2-10; optimum $\mathrm{pH} 7$.

with $\mathrm{pH}$ increasing. The possible mechanism for reduction in the activity of the Aeromonas hydrophila DNA biosensor was changes in the aptamer structure caused by $\mathrm{pH}$ changes that resulted in the possibility of a hybridization process. In addition, the changes in the activity and DNA structure of Aeromonas hydrophila in the DNA hybridization process should not be ignored.

\subsection{Temperature effect on the response of an Aeromonas hydrophila DNA biosensor}

Hybridization between pssDNA and tssDNA was performed at various temperatures (the temperature range was between 15 and $39^{\circ} \mathrm{C}$ ). The maximum response for a Aeromonas hydrophila DNA biosensor was found at $37^{\circ} \mathrm{C}$ where the peak current was $-160 \mu \mathrm{A}$ (Fig. 10). Due to the influence of heat, hydrogen bonds in hybridized strands of two ssDNA were broken gradually and their bases were separated; this matter will lead to the separation of two strands of DNA. The separation event in hybridized DNA molecules at high temperatures led to an increase in their tagging possibility against redox agents and, due to this occurrence, changes in the redox peak height and their related peak current were observed.

\section{Conclusions}

Designing a fast and accurate method against pathogenic effects of Aeromonas hydrophila will lead to increased levels of health and hygiene in the environment and human societies. In this research, the designed DNA biosensor could detect Aeromonas hydrophila with high sensitivity and specificity. Detection of this pathogenic bacterium was provided through a combination of electrochemistry and nanotechnology (use of $\mathrm{ZnS}$ nanospheres) at very low concentrations and

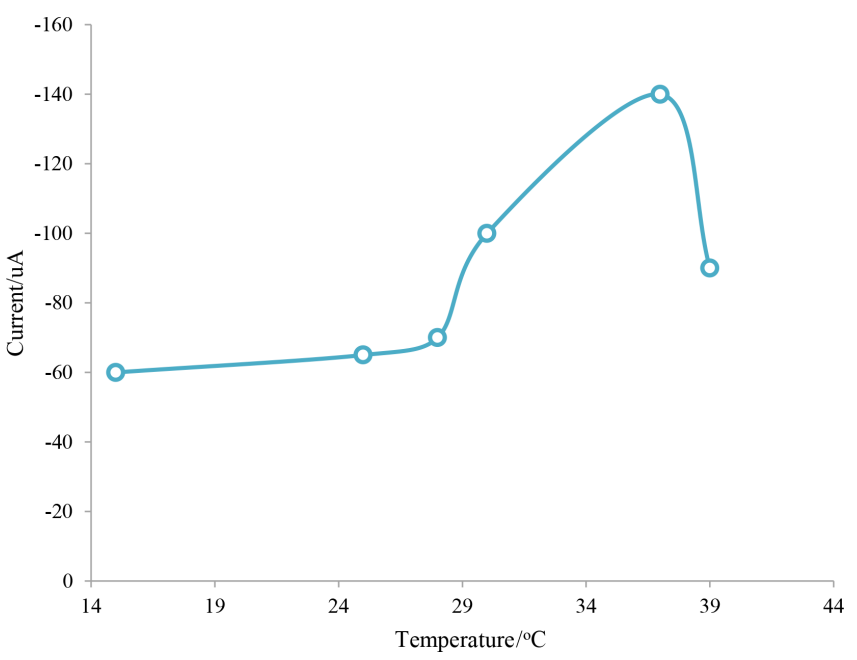

Figure 10. Temperature effect on Aeromonas hydrophila DNA biosensor response in temperature range $15-39^{\circ} \mathrm{C}$ ); optimum $37^{\circ} \mathrm{C}$.

with little amounts of analyte. The results of this research also provided a precise quantitative method to detect disease severity caused by Aeromonas hydrophila in all tissues of animals or humans. This designed DNA biosensor also showed good specificity, stability, and sensitivity after examination under various conditions.

Data availability. No data sets were used in this article.

Competing interests. The authors declare that they have no conflict of interest.

Acknowledgements. We thank all our colleagues that they provided insight and expertise and greatly assisted in this research.

Edited by: Rosario Morello

Reviewed by: two anonymous referees

\section{References}

Arrigan, D. W. M.: Electrochemical Strategies in Detection Science, 412 pp., Royal Society of Chemistry, 2015.

Austin, B. and Austin, D. A.: Bacterial fish pathogens: disease of farmed and wild fish, Springer Science and Business Media, 654 pp., 2007.

Bagheryan, Z., Raoof, J.-B., Golabi, M., Turner, A. P., and Beni, V.: Diazonium-based impedimetric aptasensor for the rapid label-free detection of Salmonella typhimurium in food sample, Biosens. Bioelectronics, 80, 566-573, 2016.

Bandaranayake, R., Wen, G., Lin, J., Jiang, H., and Sorensen, C.: Structural phase behavior in II-VI semiconductor nanoparticles, Appl. Phys. Lett., 67, 831-833, 1995. 
Beattie, K. L., Beattie, W. G., Meng, L., Turner, S. L., CoralVazquez, R., Smith, D. D., and Dao, D. D.: Advances in genosensor research, Clin. Chem., 41, 700-706, 1995

Belgrader, P., Benett, W., Hadley, D., Richards, J., Stratton, P., Mariella, R., and Milanovich, F.: PCR detection of bacteria in seven minutes, Science, 284, 449-450, 1999.

Blake, P. A., Weaver, R. E., and Hollis, D. G.: Diseases of humans (other than cholera) caused by vibrios, Ann. Rev. Microbiol., 34, 341-367, 1980.

Brumfiel, G.: Nanotechnology: A little knowledge, Nature, 424, 246-248, 2003.

Chang, B.-Y. and Park, S.-M.: Electrochemical impedance spectroscopy, Ann. Rev. Anal. Chem., 3, 207-229, 2010.

Chen, F.-C. and Godwin, S. L.: Comparison of a rapid ATP bioluminescence assay and standard plate count methods for assessing microbial contamination of consumers' refrigerators, J. Food Protect., 69, 2534-2538, 2006.

Cheng, X., Filiaggi, M., and Roscoe, S. G.: Electrochemically assisted co-precipitation of protein with calcium phosphate coatings on titanium alloy, Biomaterials, 25, 5395-5403, 2004.

Chiu, T.-C. and Huang, C.-C.: Aptamer-functionalized nanobiosensors, Sensors, 9, 10356-10388, 2009.

Cipriano, R. C., Bullock, G. L., and Pyle, S.: Aeromonas hydrophila and motile aeromonad septicemias of fish, available at: http:// digitalcommons.unl.edu/usfwspubs/134/, 1984.

Cosnier, S.: Electrochemical Biosensors, Pan Stanford Publishing, 2015.

Cumberbatch, N., Gurwith, M., Langston, C., Sack, R. B., and Brunton, J.: Cytotoxic enterotoxin produced by Aeromonas hydrophila: relationship of toxigenic isolates to diarrheal disease, Infect. Immun., 23, 829-837, 1979.

Daskalov, H.: The importance of Aeromonas hydrophila in food safety, Food Control, 17, 474-483, 2006.

de Boer, E. and Beumer, R. R.: Methodology for detection and typing of foodborne microorganisms, Int. J. Food Microbiol., 50, 119-130, 1999.

Dehghani, H., Khoramnejadian, S., Mahboubi, M., Sasani, M., Ghobadzadeh, S., Haghighi, S. M., and Negahdary, M.: Bilirubin Biosensing by Using of Catalase and ZnS Nanoparticles as Modifier, Int. J. Electrochem. Sc., 11, 2029-2045, 2016.

Deisingh, A. K. and Thompson, M.: Biosensors for the detection of bacteria, Can. J. Microbiol., 50, 69-77, 2004.

Emerich, D. F. and Thanos, C. G.: Nanotechnology and medicine, Expert Opin. Biol. Th., 3, 655-663, 2003.

Gauthier, D. T.: Bacterial zoonoses of fishes: a review and appraisal of evidence for linkages between fish and human infections, Vet. J., 203, 27-35, 2015.

Ghali, H., Chibli, H., Nadeau, J. L., Bianucci, P., and Peter, Y.-A.: Real-Time Detection of Staphylococcus Aureus Using Whispering Gallery Mode Optical Microdisks, Biosensors, 6, 20, 2016.

Goldstein, J.: Scanning electron microscopy and X-ray microanalysis: a text for biologists, materials scientists, and geologists: Plenum Publishing Corporation, 1992.

Goldstein, J., Newbury, D. E., Echlin, P., Joy, D. C., Romig Jr., A. D., Lyman, C. E., and Lifshin, E.: Scanning electron microscopy and X-ray microanalysis: a text for biologists, materials scientists, and geologists, Springer Science and Business Media, 2012.

Griffith, J. S.: The theory of transition-metal ions, Cambridge University Press, 1961.
Gunasekera, T. S., Attfield, P. V., and Veal, D. A.: A flow cytometry method for rapid detection and enumeration of total bacteria in milk, Appl. Environ. Microbiol., 66, 1228-1232, 2000.

Hamidi-Asl, E., Dardenne, F., Pilehvar, S., Blust, R., and De Wael, K.: Unique Properties of Core Shell Ag@ Au Nanoparticles for the Aptasensing of Bacterial Cells, Chemosensors, 4, https://doi.org/10.3390/chemosensors4030016, 2016.

Harikrishnan, R., Balasundaram, C., and Heo, M.-S.: Effect of chemotherapy, vaccines and immunostimulants on innate immunity of goldfish infected with Aeromonas hydrophila, Dis Aquat Org, https://doi.org/10.3354/dao02143, 2015.

Hjelm, M., Bergh, O., Riaza, A., and Nielsen, J.: Selection and identification of autochthonous potential probiotic bacteria from turbot larvae (Scophthalmus maximus) rearing units, Syst. Appl. Microbiol., 27, 360-371, https://doi.org/10.1078/07232020-00256, 2004.

Huang, L., Qin, Y., Yan, Q., Lin, G., Huang, L., Huang, B., and Huang, W.: MinD plays an important role in Aeromonas hydrophila adherence to Anguilla japonica mucus, Gene, 565, 275281, 2015.

Jacobs, J. and Bonham, A. J.: Sensitive Serologic Detection of Pathogenic Mycoplasma via Electrochemical Biosensor, The FASEB Journal, 30, 1089.1084-1089.1084, 2016.

Jiang, P. N.: Electroanalytical Chemistry Research Developments, Nova Science Publishers, 2007.

Jorgensen, J. H. and Turnidge, J. D.: Susceptibility test methods: dilution and disk diffusion methods Manual of Clinical Microbiology, 11th Edn., American Society of Microbiology, 1253-1273, 2015.

Kim, H.-S., Kim, Y.-J., Chon, J.-W., Kim, D.-H., Yim, J.-H., Kim, H., and Seo, K.-H.: Two-stage label-free aptasensing platform for rapid detection of Cronobacter sakazakii in powdered infant formula, Sensors Actuat. B-Chem., 239, 94-99, 2017.

Kiyohara, H., Nagao, K., and Yana, K.: Rapid screen for bacteria degrading water-insoluble, solid hydrocarbons on agar plates, Appl. Environ. Microbiol., 43, 454-457, 1982.

Li, X., Fu, H., He, Y., Zhai, Q., Guo, J., Qing, K., and Yi, G.: Electrochemical Aptasensor for Rapid and Sensitive Determination of Salmonella Based on Target-Induced Strand Displacement and Gold Nanoparticle Amplification, Anal. Lett., 49, 2405-2417, https://doi.org/10.1080/00032719.2016.1151888, 2016.

Liébana, S., Brandão, D., Cortés, P., Campoy, S., Alegret, S., and Pividori, M. I.: Electrochemical genosensing of Salmonella, Listeria and Escherichia coli on silica magnetic particles, Anal. Chim. Acta, 904, 1-9, 2016.

Liu, B., Xu, L., Ge, X., Xie, J., Xu, P., Zhou, Q., and Zhang, Y.: Effects of mannan oligosaccharide on the physiological responses, HSP70 gene expression and disease resistance of Allogynogenetic crucian carp (Carassius auratus gibelio) under Aeromonas hydrophila infection, Fish Shellfish Immun., 34, 1395-1403, 2013.

Ljungh, A., Popoff, M., and Wadstrom, T.: Aeromonas hydrophila in acute diarrheal disease: detection of enterotoxin and biotyping of strains, J. Clin. Microbiol., 6, 96-100, 1977.

Lopez, E. G., Gonzalez, P. G., Lopez, J. L. G., Ruiz, S. C., Areizaga, M. M., Tisaire, M. C. A., and Muñoz, M. P.: Detection of Streptococcus pneumoniae through magneto-amperometric genosensors using lytA gene-specific primers and probes, Google Patents, 2016. 
Malarkodi, C. and Annadurai, G.: A novel biological approach on extracellular synthesis and characterization of semiconductor zinc sulfide nanoparticles, Applied Nanoscience, 3, 389-395, 2013.

Mansfield, L. and Forsythe, S.: The detection of Salmonella using a combined immunomagnetic separation and ELISA end-detection procedure, Lett. Appl, Microbiol., 31, 279-283, 2000.

Mascini, M.: Aptamers in Bioanalysis, Wiley, 2009.

Megraud, F.: Advantages and disadvantages of current diagnostic tests for the detection of Helicobacter pylori, Scand. J. Gastroentero., 31, 57-62, 1996.

Nanda, J., Sapra, S., Sarma, D., Chandrasekharan, N., and Hodes, G.: Size-selected zinc sulfide nanocrystallites: synthesis, structure, and optical studies, Chem. Mater., 12, 1018-1024, 2000.

Nugent, R. P., Krohn, M. A., and Hillier, S. L.: Reliability of diagnosing bacterial vaginosis is improved by a standardized method of gram stain interpretation, J. Clin. Microbiol., 29, 297-301, 1991.

O'Sullivan, C. K.: Aptasensors - the future of biosensing? Anal. Bioanal. Chem., 372, 44-48, https://doi.org/10.1007/s00216001-1189-3, 2002.

Orazem, M. E. and Tribollet, B.: Electrochemical impedance spectroscopy, Vol. 48, John Wiley and Sons, 2011.

Ozsoz, M. S.: Electrochemical DNA Biosensors, Pan Stanford, 2012.

Palchetti, I.: Emerging Biosensor for Pesticide Detection Biosensors for Security and Bioterrorism Applications, Springer, 431442, 2016.

Palchetti, I. and Mascini, M.: Electroanalytical biosensors and their potential for food pathogen and toxin detection, Anal. Bioanal. Chem., 391, 455-471, 2008.

Pawaskar, N., Sathaye, S., Bhadbhade, M., and Patil, K.: Applicability of liquid-liquid interface reaction technique for the preparation of zinc sulfide nano particulate thin films, Mater. Res. Bull., 37, 1539-1546, 2002.

Ponnusamy, D., Kozlova, E. V., Sha, J., Erova, T. E., Azar, S. R., Fitts, E. C., and Grim, C. J.: Cross-talk among flesh-eating Aeromonas hydrophila strains in mixed infection leading to necrotizing fasciitis, P. Natl. Acad. Sci. USA, 113, 722-727, 2016.

Popoff, M. and Véron, M.: A taxonomic study of the Aeromonas hydrophila-Aeromonas punctata group, Microbiology, 94, 1122, 1976.

Pumera, M., Sanchez, S., Ichinose, I., and Tang, J.: Electrochemical nanobiosensors, Sensor. Actuat. B-Chem., 123, 1195-1205, 2007.

Radi, A.-E., Acero Sánchez, J. L., Baldrich, E., and O'Sullivan, C. K.: Reusable Impedimetric Aptasensor, Anal. Chem., 77, 63206323, https://doi.org/10.1021/ac0505775, 2005.

Raus, J. and Love, D. N.: Characterization of coagulase-positive Staphylococcus intermedius and Staphylococcus aureus isolated from veterinary clinical specimens, J. Clin. Microbiol., 18, 789$792,1983$.

Retter, U. and Lohse, H.: Electrochemical impedance spectroscopy Electroanalytical Methods, Springer, 149-166, 2005.
Ruzicka, F., Horka, M., Hola, V., Mlynarikova, K., and Drab, V.: Capillary Isoelectric Focusing-Useful Tool for Detection and Quantification of Lactic Acid Bacteria in Milk, Food Anal. Methods, 9, 3251-3257, 2016.

Sahoo, S., Parveen, S., and Panda, J.: The present and future of nanotechnology in human health care, Nanomed.-Nanotechnol., 3, 20-31, 2007.

Sebastian, S., Colpas, G. J., Ellis-Busby, D. L., Harvard, J. M., and Sanders, M. C.: Methods, peptides, and biosensors useful for detecting a broad spectrum of bacteria, Google Patents, 2016.

Shachar, Y., Wu, W., Chen, T., Farkas, L., Jordan, B., Luboff, P., and Zimmerman, K.: Method and apparatus for forming of an automated sampling device for the detection of Salmonella enterica utilizing an electrochemical aptamer biosensor, Google Patents, 2016.

Sheikhzadeh, E., Chamsaz, M., Turner, A., Jager, E., and Beni, V.: Label-free impedimetric biosensor for Salmonella Typhimurium detection based on poly [pyrrole-co-3-carboxyl-pyrrole] copolymer supported aptamer, Biosens. Bioelectron., 80, 194-200, 2016.

Shoemaker, C. A., Klesius, P. H., and Evans, J. J.: Prevalence of Streptococcus iniae in tilapia, hybrid striped bass, and channel catfish on commercial fish farms in the United States, Am. J. Vet. Res., 62, 174-177, 2001.

Sommerset, I., Krossøy, B., Biering, E., and Frost, P.: Vaccines for fish in aquaculture, Expert Rev. Vaccines, 4, 89-101, 2014.

Suehiro, J., Hamada, R., Noutomi, D., Shutou, M., and Hara, M.: Selective detection of viable bacteria using dielectrophoretic impedance measurement method, J. Electrostat., 57, 157-168, 2003.

Sumner, S. S. and Taylor, S. L.: Detection method for histamineproducing, dairy-related bacteria using diamine oxidase and leucocrystal violet, J. Food Protect., 52, 105-108, 1989.

Templier, V., Roux, A., Roupioz, Y., and Livache, T.: Ligands for label-free detection of whole bacteria on biosensors: A review, TrAC Trends in Analytical Chemistry, 79, 71-79, 2016.

Viswanatan, S., Manikandan, S., and Haniffa, A.: Evaluation of resistance against Antibiotics, Antiseptics and Disinfectansts in Aeromonas hydrophila isolated from Marketed Fishes, Pharmaceutical and Biological Evaluations, 2, 40-46, 2015.

Wang, J.: Analytical Electrochemistry, Wiley, 2006.

Wang, L. and Hong, G.: A new preparation of zinc sulfide nanoparticles by solid-state method at low temperature, Mater. Res. Bull., 35, 695-701, 2000.

Xie, C., Mace, J., Dinno, M., Li, Y., Tang, W., Newton, R., and Gemperline, P.: Identification of single bacterial cells in aqueous solution using confocal laser tweezers Raman spectroscopy, Anal. Chem., 77, 4390-4397, 2005.

Zhang, X., Ju, H., and Wang, J.: Electrochemical Sensors, Biosensors and their Biomedical Applications, Elsevier Science, 2011.

Zourob, M., Elwary, S., and Turner, A. P.: Principles of bacterial detection: biosensors, recognition receptors and microsystems, Springer Science and Business Media, Springer-Verlag New York, 970 pp., https://doi.org/10.1007/978-0-387-75113-9, 2008. 